\title{
Dinâmica Tecnológica e Ambiente Seletivo em Genética de Suínos*
}

\author{
Júlio Eduardo Rohenkohl \\ UFSM \\ Orlando Martinelli Júnior \\ UFSM
}

Recebido: 6/5/2008 Aprovado: 18/11/2008

\section{Resumo}

O artigo discute elementos do sistema tecnológico do segmento de genética suína - especialmente as trajetórias tecnológicas e os atributos do ambiente seletivo, tais como os aspectos regulatórios e organizacionais. $\mathrm{O}$ texto também identifica as mudanças recentes nas configurações tecnológicas e organizacionais no segmento, destacando o surgimento de novos agentes econômicos e fluxos de informações tecnológicas e científicas.

Palavras-Chave | Tecnologia; Ambiente Seletivo; Genética Suína

Códigos JEL | O32; O33; Q16

\footnotetext{
Este artigo está amparado - especialmente no plano empírico - por dois estudos anteriores. O primeiro é o Relatório de Pesquisa do projeto de Diretório da Pesquisa Privada (convênio FINEP-FUNDUNESP), no qual foi realizado um estudo específico sobre a genética suína nacional e sua contextualização no plano internacional. O segundo é a tese de doutorado de Rohenkohl (2006). Os autores agradecem os comentários valiosos dos pareceristas da RBI. As falhas remanescentes são de responsabilidade exclusiva dos autores.
} 


\begin{abstract}
This article makes a discussion on the elements of the technological system in the swine genetics segment, especially the technological trajectories and the selective environment attributes such as the regulatory and organizational aspects. The text also identifies the recent changes in the technological and organizational configurations in the segment, emphasizing the arising of new economic agents and technological and scientific information flux.
\end{abstract}

KEyw ords | Technology; Selective Environmental; Swine Genetics

JEL-Codes | O32; O33; Q16

\title{
1. Introdução
}

A dinâmica tecnológica tem uma natureza intrinsecamente sistêmica, cujas dimensões econômicas, científicas, sociais e institucionais são as mais relevantes. Longe de ser apenas explicada pelo avanço do conhecimento científico e/ou pelas mudanças nas necessidades subjetivas de consumidores, o curso da inovação perpassa diversas etapas, interagindo com diversos ambientes e loci seletivos. Destacam-se, por exemplo, o plano da ciência - e da geração de conhecimento científico -, o dos aspectos judiciais e regulatórios, o da esfera produtiva e estratégica das firmas, e o dos atributos lato sensu que compõem o mercado.

Em setores agroalimentares as referências analíticas sistêmicas são particularmente importantes, uma vez que podem dimensionar e/ou relativizar as trajetórias tecnológicas e seus impactos socioeconômicos (positivos ou negativos) ao longo do tempo. Nesses setores, além das trajetórias tecnológicas, das variantes de comportamento das firmas no ambiente concorrencial, torna-se fundamental considerar também, por um lado, os aspectos cognitivos e subjetivos dos consumidores - cujos limites são históricos e inerentemente vinculados a valores socioculturais mais estáveis (por exemplo, a convenção social sobre o padrão de consumo ao longo do tempo). Por outro, atuam fortemente os aspectos institucionais normativos, especialmente os 
de natureza formal (por exemplo, a evolução da legislação sobre práticas sanitárias na produção, na comercialização e no consumo de alimentos).

No âmbito do paradigma tecnológico em curso, esses determinantes sistêmicos se consubstanciam em dois aspectos importantes presentes nas trajetórias tecnológicas ${ }^{1}$ dos setores agroalimentares. O primeiro é que não se observa a introdução exitosa de um grande número de produtos finais radicalmente diferenciados em seus atributos mais importantes. A inovação em produtos é claramente do tipo incremental. O segundo, atrelado ao anterior, é que, devido à progressiva incorporação de tecnologias genéricas nesses setores, se observa a progressiva segmentação das etapas produtivas de transformação industrial e, concomitantemente, o processo de "decommoditização" do produto primário - ou artefato básico. Isso implica uma trajetória de maior diferenciação qualitativa do próprio produto primário, bem como do processado. Em ambos os tipos de produtos, ampliam-se, portanto, as possibilidades de agregação de valor no mercado, seja no mercado final, ou mesmo no intermediário (Pessanha $\&$ Wilkinson, 2003; Eymard-Duvernay, 1989, 1995; Chevassus-Lozza \& Gallezot, 1995; Andersen, 2000; Furtado, 2004).

Nessa perspectiva, um caso interessante a ser analisado é o da suinicultura, cujo processo de "decommoditização" do "produto primário" - o animal e sua carne - é cada vez mais evidente, especialmente pela incorporação de insumos tecnológicos mais intensivos e complexos. No plano do mercado, isso se tem traduzido na maior segmentação dos mercados (do produto primário e do processado), bem como na maior complexidade dos elementos competitivos neles presentes. A tendência é de realçar as vantagens da capacitação tecnológica dinâmica em detrimento das vantagens concentradas na base produtiva primária.

O segmento de genética suína é um segmento fundamental para a compreensão dessa dinâmica tecnológica, uma vez que é um polo importante gerador de inovações, especialmente pela oferta de novas linhas genéticas, que influenciam a velocidade de crescimento dos suínos, a quantidade de carne na carcaça, a qualidade da carne e o número de leitôes por parto. Isso tem sido possível tanto pelo avanço e uso do maior conhecimento em genética e em biotecnologia, mas também pela

1 Um paradigma tecnológico é a definição de problemas relevantes a serem resolvidos com um corpo específico de conhecimento. Dito de outra maneira, ele é uma lógica de entendimento e solução de problemas que abre um conjunto de possibilidades de pesquisa aplicada e de ação técnica e econômica. O paradigma dá a amplitude, o horizonte, das possibilidades de processo produtivo e de diferenciação dos produtos. Por sua vez, a trajetória tecnológica pode ser definida como o incremento nas alternativas econômicas e técnicas (trade-off), efetivamente seguidas dentre as possibilidades de um paradigma tecnológico. É a direção de avanço efetivo dentro de um paradigma. As melhorias no trade-off adotadas são compatíveis com a heurística do(s) paradigma(s) e influem na produtividade e na qualidade dos produtos. Ver Dosi (1982) e Cimoli e Dosi (1994). 
maior incorporação de ativos complementares, tais como os softwares estatísticos e a tecnologia da informação.

No plano econômico, por sua vez, tem-se a constituição de um mercado internacionalizado, composto fundamentalmente por firmas multinacionais importantes. Criaram-se também novas estratégias organizacionais de desenvolvimento de linhas genéticas, envolvendo mais fortemente parcerias com universidades, centros de pesquisa e com firmas locais em diversos países. ${ }^{2}$ Pode-se afirmar que ocorre a divisão de tarefas no processo inovativo.

Considerando-se as etapas de capacitação em genética suína, a fase de maior complexidade tecnológica é a da pesquisa aplicada (P) a produto e processos - novas técnicas de reprodução, novas relações entre genes e características. Nessa etapa, as firmas multinacionais de genética atuam globalmente com a estratégia de desenvolvimento genético de linhas sintéticas puras centralizadas na matriz, em parcerias com universidades e centros de pesquisa estrangeiros, com a exportação de bisavós, bisavôs, sêmen ou embriôes para as suas filiais em diversos países. Há a multiplicação local da genética, feita em granjas de alto padrão sanitário espalhadas em diversos países em todos os continentes. Em seguida tem-se a etapa do desenvolvimento (D) de produto (novos machos terminadores, novas linhas fêmeas) e de processo (cruzamentos entre linhas ainda não efetuados para obtenção de avós e matrizes), e finalmente a etapa de adaptação (A) (ao clima e às condições do mercado local) e multiplicação. Pode-se afirmar que o Brasil se insere fundamentalmente na etapa (A), no entanto iniciou - mas ainda não consolidou - operações de participação na etapa (D) e pouco atua na etapa (P).

No caso brasileiro, após a Embrapa ter um papel de destaque na evolução do melhoramento de suínos no Brasil, ocorrido a partir dos anos 1960, atualmente o desenvolvimento genético efetuado é dominado por grupos empresariais especializados e objetiva a obtenção de linhas genéticas com características específicas, tais como o aumento de prolificidade, o incremento da velocidade de crescimento, a melhoria da qualidade da carne. As granjas nacionais de seleção fenotípica de suínos puros, como as existentes no Sul do Brasil, foram deslocadas do mercado pelas firmas de genética, uma vez que diversas empresas estrangeiras entraram no setor brasileiro de genética de suínos, tais como a Topigs, Dan Bred, Pen Ar Lan, e Génétiporc. A Embrapa, por sua vez, trabalha fundamentalmente com a perspectiva de incrementar o seu banco genético a partir de raças "nativas", descendentes dos primeiros suínos trazidos por portugueses e espanhóis.

2 Alguns desses temas serão retomados e discutidos adiante no trabalho. 
A indústria suinícola brasileira tem-se destacado no âmbito internacional. ${ }^{3}$ Esse bom desempenho, porém, não está necessariamente garantido no futuro. Além das barreiras tarifárias e não tarifárias, bastante presentes no comércio internacional de carnes em geral - e em especial na suína -, é preciso destacar a importância competitiva crescente de fatores tecnológicos mais complexos, integrados e sistêmicos. Em diversos países observam-se instituições públicas de pesquisa e empresas privadas engajadas em programas conjuntos de melhoramento genético, ao lado de outros segmentos também fornecedores de insumos à indústria suinícola, tais como o de medicamentos veterinários e de nutrição animal.

Este artigo tem como proposta discutir - numa perspectiva sistêmica - as principais características e mudanças recentes nas configurações tecnológicas e organizacionais no segmento de genética suína. Não se pretende aqui propor resoluçōes de problemas técnico-econômicos concretos e/ou identificados no segmento suinícola. A proposta é utilizar ferramentas teóricas e analíticas para ajudar a identificação dos elementos tecnológicos, dos aspectos institucionais, regulatórios e das formas organizacionais presentes no sistema tecnológico do desenvolvimento genético em suínos. Para tanto, após esta introdução, a segunda seção dedica-se à discussão sobre as noções de sistema tecnológico, de sistema de mercado, e a articulação entre elas, delineando o ambiente seletivo setorial. Esses constructos teóricos permitem focar a dinâmica tecnológica e econômica das atividades de genética de suínos em diversos planos analíticos. Em seguida, o artigo discute a evolução e as características de duas configurações inovativas do desenvolvimento genético, demonstrando inclusive por meio de exemplos empresariais - a importância que uma adequada concatenação dos elementos tecnológicos, econômicos e socioinstitucionais podem ter na geração de sinergias e spillovers para a capacitação tecnológica local. Por fim, apresentam-se algumas considerações finais. Nesta parte, sem a pretensão de aprofundar a discussão, o artigo pode, em certo sentido, contribuir para o aprimoramento da formulação de política industrial, tecnológica e de inovação para o Brasil, uma vez que evidencia alguns novos atores, fluxos tecnológicos e econômicos do setor. Isso é importante porque, embora se tenha um processo inovativo do tipo incremental -

3 O Brasil é um importante player mundial no mercado de carnes suínas. Em 2006, os quatro maiores produtores mundiais foram a China, com 50 milhões de toneladas, a União Europeia (com 25 países), com 21 milhões de toneladas, os EUA, próximo a 10 milhões de toneladas, e o Brasil, com cerca de 3 milhões de toneladas. Esses 4 maiores produtores mundiais de carne suína detêm juntos cerca de $80 \%$ da produção mundial (ABIPECS, 2008). Em 1977, o plantel brasileiro de suínos era de 36,8 milhões de cabeças e a produção havia sido de 834 mil toneladas (Gomes et al., 1992). Em 2007, o rebanho estimado era de 36,8 milhões de cabeças e a respectiva estimativa de produção alcançava 2.997 milhões de toneladas (ACSURS, 2008). Portanto, decorridos 30 anos, com o mesmo tamanho de rebanho, a produção é $259 \%$ maior. 
e aparentemente uma conformação institucional e organizacional estabilizada -, é necessário notar que diversas mudanças incrementais em sequência e em ritmo acelerado acarretam um salto tecnológico com implicaçôes profundas nos arranjos institucionais e nos sistemas de mercado. Assim, este artigo pode fornecer subsídios para conscientizar membros da "cadeia produtiva", formuladores de política e cientistas de áreas correlatas à economia, da dimensão e da potencialidade da mudança tecnológica em curso, e de suas consequências produtivas e comerciais, para que possam envidar esforços que mantenham e aumentem a competitiva inserção das exportaçōes de carne suína brasileira, e com ela a renda gerada pelo setor. ${ }^{4}$

\section{Sistema tecnológico e ambiente seletivo em genética suína}

O sistema tecnológico (ST) é definido como uma rede dinâmica de agentes interagindo em uma área econômica/industrial específica, sob uma infraestrutura institucional particular, e dedicada à geração, difusão e utilização de tecnologia. Esse sistema é delineado em termos de fluxos de conhecimento e de competência científica e empresarial em lugar dos tradicionais fluxos de bens e serviços (Carlsson \& Stankiewicz, 1991).

Os componentes e o funcionamento de um ST contribuem para a identificação e estruturação de possibilidades técnicas aplicadas a serem convertidas em oportunidades de negócio em interação com o sistema de mercado (SM). Este, por sua vez, é o espaço, perpassado e delimitado por regras e convenções de relacionamento, em que compradores e vendedores trocam o direito sobre mercadorias, ou seja, uma estrutura socioeconômica em que ocorre a comercialização de direitos. O conjunto de regras e de convençôes sociais incentiva, mas também constrange, possibilidades comerciais e produtivas/tecnológicas aos participantes, compondo um padrão de concorrência industrial específico. Portanto no SM a concorrência e a dinâmica inovativa são elementos interligados e dinâmicos. Assim, o ST é identificado com a estrutura setorial técnico-produtiva, que abriga também instituições e organizações que contribuem para a geração de conhecimento e de inovações típicas do setor produtivo. O SM é identificado com um conjunto mais restrito de artefatos

4 O produtor de suínos exerce um papel subordinado na escolha e difusão das tecnologias aplicadas ao desenvolvimento e ao melhoramento genético, bem como àquelas aplicadas a formulações de medicamentos e de rações. Por isso não é tema destacado na discussão dos temas deste artigo. Entretanto, é alvo de preocupação dos autores, porque carrega parte dos custos (pocilgas, terra, equipamentos, mão de obra, financiamentos) e porque tem a sua renda reduzida toda vez que as exportações brasileiras de carne suína sofrem um revés - conforme pontuado nas considerações finais. 
(em geral substitutos próximos) e seus atributos técnicos, mas especialmente com os elementos institucionais e socioeconômicos (tais como renda, padrão de consumo, valores culturais etc.).

As configurações do ST e do SM apresentam sensibilidades distintas às instituições. Do mesmo modo, as organizações que delas participam perseguem objetivos diferentes, o que garante uma convivência com relativa independência, interpenetrando-se e propagando efeitos complementares. O ST possibilita a constituição da base de conhecimento para a inovação, a criação de possibilidades técnicas aplicadas. Já o SM é o espaço de concorrência entre firmas, no qual algumas possibilidades técnicas são consideradas oportunidades de negócios, de modo que a inovação e as vantagens competitivas associadas à tecnologia são remuneradas.

A configuração do Ambiente de Seleção (AS) - Figura 1 - é resultado e dependente das condições interativas entre o ST e o SM, isto é, da interação entre agentes (entre firmas e entre firmas e consumidores) no processo de concorrência lato sensu. Embora não seja um processo aleatório, uma vez que os agentes possuem uma história de conhecimentos adquiridos que condiciona o seu comportamento - e as firmas, especificamente, inovam a maioria das vezes no marco de uma trajetória tecnológica -, não há como estabelecer precisamente, ou provavelmente, como os agentes se vão portar ao longo do tempo. Cada momento no AS é único e inédito, em que há uma combinação ímpar de habilidades mutantes e diversas - de diferentes concorrentes -, com as características peculiares do ambiente institucional.

Nesse plano do AS, no qual se tem imbricado conjuntamente as forças do processo concorrencial e as do processo inovativo, é que, segundo Metcalfe (2003), se tem a base para a formulação de políticas de inovação.

FIGURA 1

Ambiente de seleção

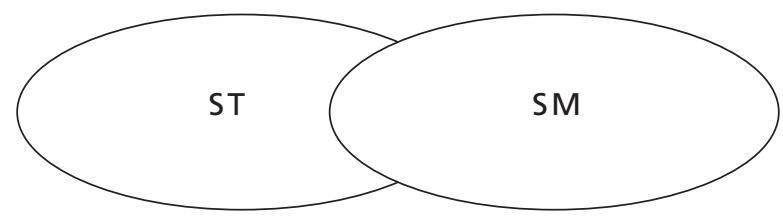

Fonte: elaborado pelos autores. 
No caso do setor suinícola, o desenvolvimento da criação de animais em escala industrial permitiu às firmas se especializarem e se identificarem como abatedoras ou como fornecedoras de raçôes, de medicamentos veterinários e aditivos ou de genética suína. Essa especialização, por sua vez, permite que muitos abatedores se comportem como tomadores de tecnologias e se concentrem no aprimoramento das capacidades gerenciais de produção e de distribuição da carne e dos seus derivados. Além disso, a ação peculiar de consumidores e de organismos de regulação perpassam as açôes das firmas, induzindo, por vezes, novos rumos comportamentais - e novas agendas de pesquisa -, voltados para a segurança quanto à sanidade do alimento e do consumidor.

Os agentes que participam dos ST e do SM da carne suína são as universidades (e centros de pesquisa) - produtores de conhecimento aplicado e avaliadores do produto -, os setores "insumidores" de medicamentos, raçôes, aditivos, os criadores independentes e as firmas integradoras/abatedoras de animais. As últimas, como criadoras de animais, vendedoras de produtos in natura e processadoras de alimentos derivados da carne, são as principais usuárias das inovaçôes. Elas relacionam-se através da troca de informaçōes técnicas e/ou de produtos, ou pelo compartilhamento de conhecimento, conforme as suas competências. Na suinicultura industrial há uma grande integração nos fluxos produtivos e de informaçôes entre os agentes na cadeia produtiva, que por sua vez está envolta nos elementos do sistema como um todo.

As características das mercadorias transacionadas - raçôes, medicamentos, animais, carne suína - são transformadas pela inovação. Ao mesmo tempo, tais características refletem as instituições do SM. Os atributos da mercadoria precisam ser compatíveis - ou não destoantes - com os elementos socioinstitucionais, o padrão de consumo, a legislação sanitária e com o direito de propriedade do mercado.

Esse recurso analítico permite ampliar a identificação de elementos econômicos, tecnológicos e socioinstitucionais para a configuração do sistema tecnológico. A configuração apresentada na Figura 2 destaca a produção do "produto-porco" e a carne suína, identificando, em diversos planos, as tecnologias que são combinadas para produzi-los, os agentes, e os elementos do ST e do SM específicos, isto é, pertencentes ao mesmo ambiente socioinstitucional e/ou seletivo. São identificadas as tecnologias genéricas combinadas para a produção e os agentes que se relacionam para tanto. Este é um plano mais amplo, identificando a cadeia produtiva da suinocultura industrial com o ST, composto pelas tecnologias (T1, T2, T3 etc.) associadas à criação de suínos e responsáveis pelas mudanças no "produto-suíno" (P1) - o artefato básico - e em sua carne (P2). Esses novos produtos, que visam a diferentes clientes (C1, C2, C3, C4), estão envoltos em diversos elementos socioinstitucionais e regulatórios dos ambientes nacional e internacional. 
FIGURA 2

Sistema tecnológico e de mercado do suíno caracterizado a partir dos produtos

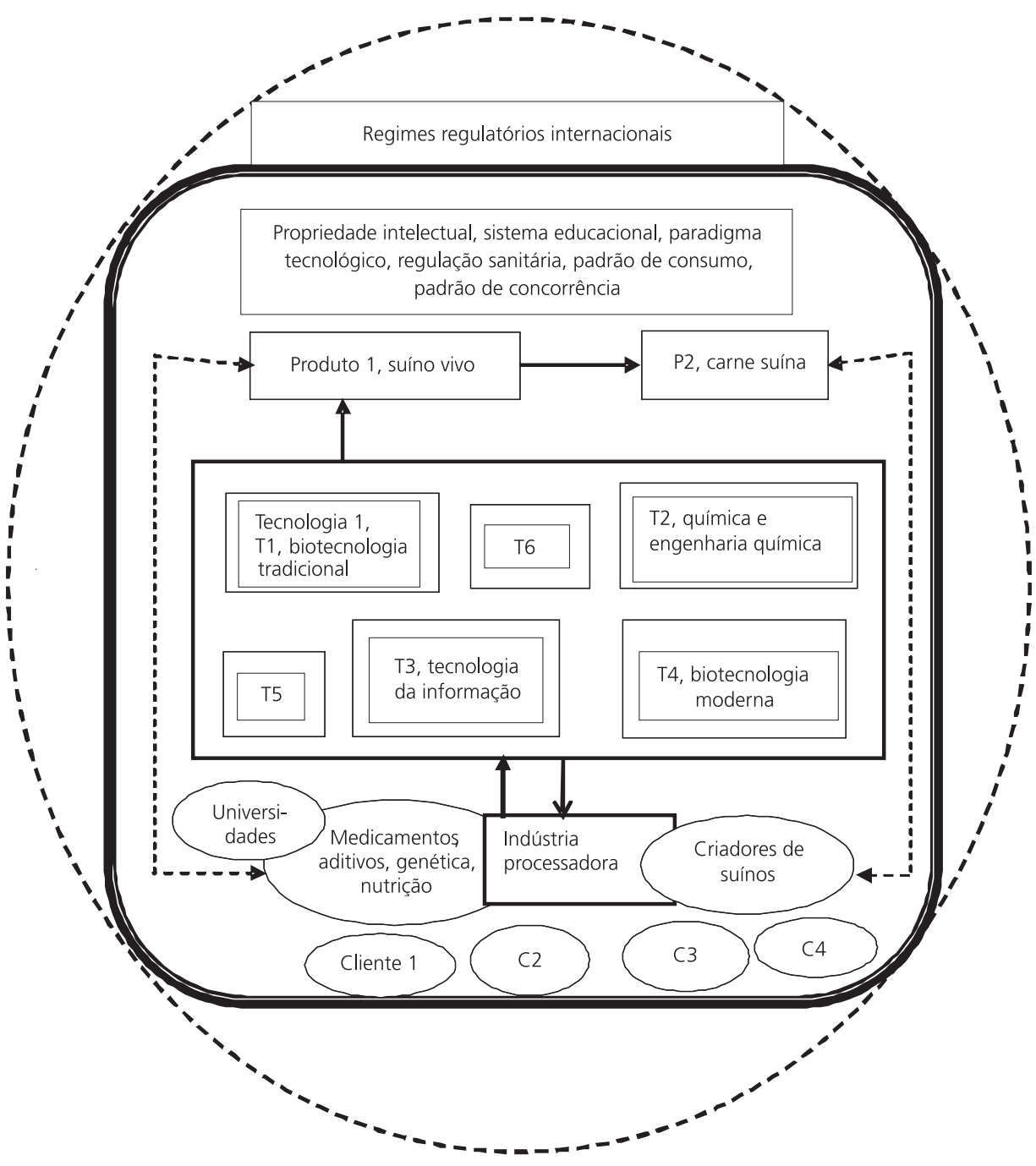

Fonte: adaptado pelos autores de Carlsson et al. (1999). 
O segmento de genética suína é um sub-bloco tecnológico do sistema acima. Diz respeito à pesquisa e ao desenvolvimento $(\mathrm{P} \& \mathrm{D})$ específicos para a criação de novos métodos de seleção, novas técnicas de reprodução e novos produtos (linhas genéticas). Pode-se denominar por desenvolvimento genético o esforço efetuado apenas por firmas especializadas em genética animal e que envolve a P\&D para obtenção de novas linhas genéticas híbridas mais produtivas e/ou que geram diferenças qualitativas na carcaça e na carne.

Paralelamente, há outro esforço de adaptação das linhas genéticas de alto padrão às necessidades ou às percepções de sistemas de mercado específicos de abatedores ou de criadores independentes. Isso implica o cruzamento de linhas genéticas puras para a obtenção de um híbrido de primeiro cruzamento. Essa atividade, aqui denominada por melhoramento genético, se restringe a um incremento em uma geração de animais das linhas já desenvolvidas, o qual pode ser empreendido pelas firmas de genética, pelas integradoras/abatedoras ou pelos produtores independentes. A característica melhorada não é fixada de modo que a sua transmissão à geração seguinte não é garantida.

Considerando o exposto, o desenvolvimento genético consiste na oferta de reprodutores, machos e fêmeas, de alta qualidade e especificidade. É uma base tecnológica importante para a criação animal porque influi na capacidade dos animais de melhor aproveitarem os atributos do meio, em especial da nutrição e do manejo sanitário. Além disso, o melhoramento permite incremento dos fatores social e economicamente relevantes. Entre os fatores de importância social, estão o bem-estar dos animais, o impacto da criação sobre o ambiente e as consequências do consumo da carne para a saúde humana.

Em uma perspectiva histórica, até meados da década de 1950, os produtores rurais elaboravam artesanalmente o melhoramento genético baseados no fenótipo (características de conformação do animal apreciadas com o uso dos sentidos) do animal que lhes agradasse. A partir de então, a quantificação de desempenho produtivo do animal e a qualidade da carcaça passaram a nortear a seleção dos animais e surgiram as primeiras firmas especializadas em genética suína.

Nos anos de 1980, o casamento entre pesquisa (técnicas de reprodução), melhoria de produto, multiplicação e comercialização expandiu-se internacionalmente com firmas europeias, tais como PIC, JSR, NPD, Dalland, Pen Ar Lan, Dan Bred, entre outras. Generalizou-se a inseminação artificial e acrescentou-se o uso de programas estatísticos informatizados.

A década de 1990 é marcada pelo início do uso da genética molecular e pela referência do padrão sanitário elevado nas granjas de criação. A genética molecular 
propiciou um novo método, mais preciso, para a previsão de desempenho produtivo de animais quanto às características de baixa herdabilidade, mas de importância socioeconômica. Com ela consolidou-se a busca por inovaçôes, originando uma sistemática que pode ser chamada de desenvolvimento genético. Desde então, há $\mathrm{P} \& \mathrm{D}$ estruturada aplicada à genética suína. Com isso, configura-se um caráter internacional, multifacetado, sistêmico, ao modelo de inovação do segmento industrial de insumos para suínos (Rohenkohl, 2006).

A partir desse quadro, pode-se adaptar a contribuição de Carlsson et al. (1999), para focar o segmento de genética suína, identificando assim as potencialidades/ possibilidades tecnológicas e de seus usos mais efetivos pelos agentes no mercado. Considerando uma dimensão cognitiva maior denominada por "espaço de estado", pode-se definir um reduzido recorte de possibilidades tecnológicas utilizado para a criação de inovações na indústria, o "espaço de desenho". Neste, está agregado todo o conhecimento relevante contido nas pessoas e nas organizaçóes, e utilizado para produzir inovações. Ele pode aumentar e transformar-se a partir de novas competências geradas pelos agentes e/ou pelas organizaçóes. No entanto, apenas uma parte das possibilidades do espaço de desenho transforma-se em oportunidades de negócios. Mudanças radicais na base de conhecimento podem originar outros espaços de desenho, e o ST acaba criando conhecimento aplicado em mais de uma tecnologia. Quanto maior for a capacidade dos agentes no sistema de receber e de absorver conhecimento técnico, maiores as chances de que oportunidades de negócio sejam identificadas (Carlsson \& Eliasson, 2003:444). Essa heurística de busca (o espaço de possibilidades técnicas e o espaço de desenho), que reduz o campo de criação de inovaçôes, é compatível e complementar às noçôes de paradigma e de trajetória tecnológica.

Logo, os contornos do ST, referentes aos tipos de conhecimentos utilizados e aos quais os agentes envolvidos não são fixos, e a sua transformação, alicerçada em nova base de conhecimento multifacetada (formada por tecnologias genéricas combinadas) que altera o(s) espaço(s) de desenho, provocam transformaçōes nos produtos para cuja produção contribui com conhecimento aplicado. Com isso, mudam as possibilidades de produtos a serem selecionados no SM. Não há uma correspondência unitária entre tecnologia e produto, ele é a composição de diversas tecnologias genéricas aplicadas a um segmento. Sendo assim, os limites do ST originam-se em vários espaços de desenho que crescem, amadurecem, subdividemse ou convergem. Um exemplo é dado pela indústria farmacêutica, cujo ST estava embasado na química e na engenharia química e agora está sustentado também na biotecnologia moderna (Carlsson \& Eliasson, 2003:441-442). 
FIGURA 3

Planos das possibilidades inovativas em genética suína

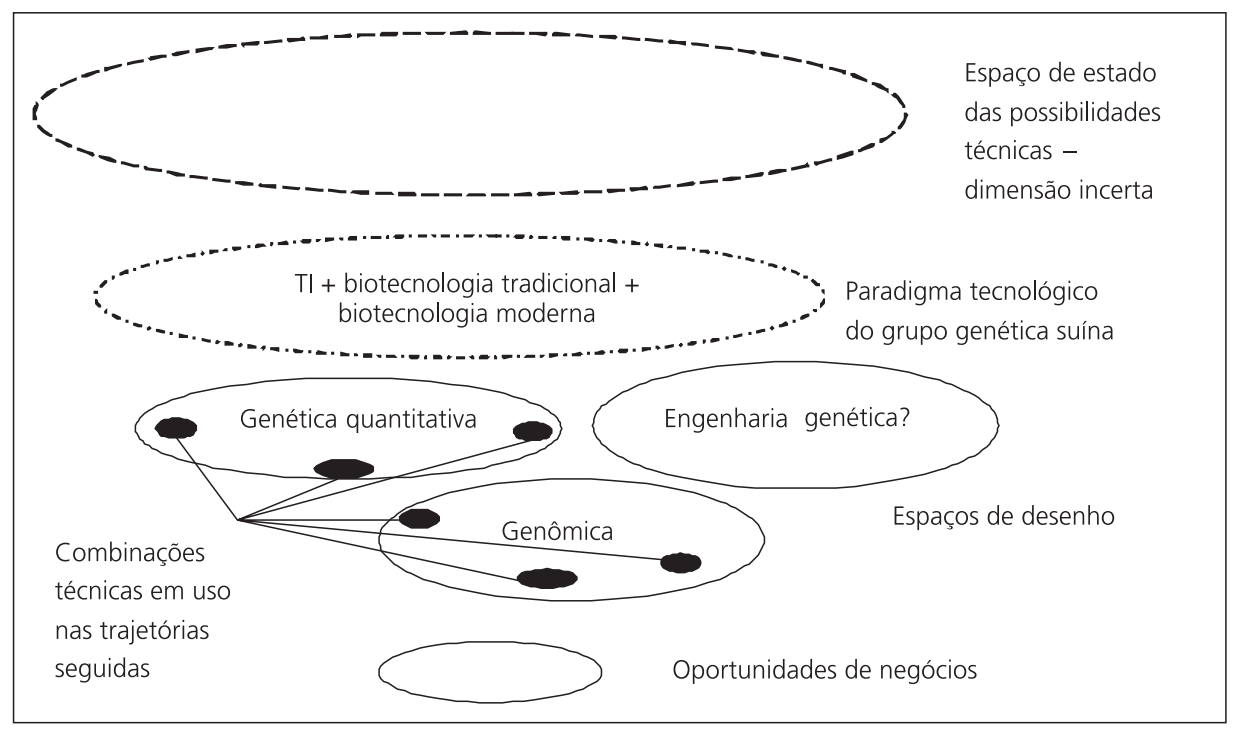

Fonte: elaborado pelos autores com base em Carlsson e Eliasson, 2003.

Para o segmento de genética suína, a Figura 3 sintetiza os planos das possibilidades técnicas até que sejam identificadas as oportunidades de negócios no SM. Partindo do "espaço de estado" com todas as combinaçôes técnicas possíveis relacionadas com o grupo insumidor de genética, há uma primeira delimitação com o paradigma tecnológico utilizado no grupo de genética. Aí aparecem as tecnologias genéricas que combinadas geram a lógica de solução de problemas. O conhecimento das pessoas e das organizaçóes, especializado em algumas ramificaçóes das tecnologias genéricas, é aplicado para operacionalizar a lógica do paradigma e define o espaço de desenho, uma delimitação mais precisa das possibilidades técnicas a serem exploradas em um período. Destas, algumas efetivamente são trilhadas nas trajetórias tecnológicas e originam oportunidades de negócios.

O paradigma tecnológico com que o grupo de genética suína se defronta é uma lógica de solução de problemas que combina conhecimentos da TI e da biotecnologia. Os softwares são utilizados pelas firmas para o controle e armazenamento de dados de desempenho dos animais, gerenciamento de granjas, análise qualitativa da carcaça e da carne, transmissão on-line de dados de desempenho dos animais e 
de qualidade da carne e da carcaça. A biotecnologia está presente na $\mathrm{P} \& \mathrm{D}$ com a inseminação artificial, a sexagem de sêmen, o congelamento de sêmen e de embriōes, e a genômica. Os softwares estatísticos e o sequenciamento genético são combinados na genômica, para orientar o processo de seleção de animais.

Considerando os "espaços de desenho", pode-se conceber dois campos de possibilidades específicas dentro da grande amplitude do paradigma. O primeiro utiliza a TI e a biotecnologia tradicional (inseminação artificial) e se estabelece em torno da genética quantitativa, ou seja, o direcionamento da seleção a partir de um banco de dados de desempenho dos animais para fatores produtivos relevantes. Nele ocorre uma trajetória tecnológica, dominante até os anos de 1980, que levou à melhoria de conversão alimentar, redução da espessura de toucinho e aumento do percentual de carne na carcaça dos animais. O segundo "espaço de desenho" acrescenta à TI a biotecnologia moderna e algumas novas técnicas de reprodução (transferência de embriōes e sexagem de sêmen). Nele é seguida uma trajetória tecnológica, desde os anos de 1990, que combina a genômica com a genética quantitativa para a seleção de animais, melhorando o trade-off entre quantidade e qualidade de carne (gordura intramuscular, cor e capacidade de retenção de água). O paradigma tecnológico possibilita a ampliação do segundo "espaço de desenho", delineando novos objetivos para a seleção ao longo de uma trajetória tecnológica, tais como a obtenção de animais mais resistentes a doenças, o aumento da prolificidade das porcas e a redução do impacto ambiental. A ampliação do "espaço de desenho" pode, inclusive, desencadear outra trajetória tecnológica, por exemplo, envolvendo o uso da engenharia genética.

Nesse contexto, embora possa haver algumas diferenças nacionais e regionais, há aspectos institucionais importantes que transcendem as fronteiras nacionais e perpassam fortemente o segmento de genética suína. Esses são os casos da propriedade intelectual e do padrão de sanidade, que, embora possuam algum grau de peculiaridade nacional, estão condicionadas a regimes internacionais, estabelecidos ou monitorados por órgãos internacionais a exemplo da Organização Mundial de Comércio (OMC).

No caso da propriedade intelectual, as condiçôes institucionais para a apropriação de conhecimento relacionado com o desenvolvimento genético abrangem o direito autoral de softwares estatísticos usados na genética quantitativa, o registro de marca das firmas e de produtos (machos reprodutores e matrizes) e o requerimento de patentes em genética molecular.

A obtenção de patentes de métodos de identificação de genes ou segmentos genéticos de suínos ligados à transmissão hereditária de uma característica é possível, 
mas, no momento, apresenta-se pouco eficaz para a remuneração pelo conhecimento e, consequentemente, para a publicidade dele. ${ }^{5}$ Há poucos genes que estão ligados a uma característica em todas as populações de suínos. $\mathrm{O}$ halotano (ligado ao estresse do animal) e o gene da carne ácida são universais. Para outras relações entre genes e características, mudando a população e/ou o ambiente, a característica pode não se expressar ou pode estar ligada a outra região do genoma. Devido a essa complexidade da interação entre genética e ambiente, é muito valorizado o êxito em fixar em uma população a característica econômica desejada. Essa mesma complexidade, aliada à diversidade de técnicas de relacionar genes às características, desafiam a extensão da propriedade intelectual ao patenteamento de genes, tornando-o, para o emprego utilizado no momento no desenvolvimento genético, pouco eficaz. A relação encontrada em uma população animal pode não se repetir em outra, além de que a mesma relação entre genes e característica pode ser estabelecida com outra técnica. Requerer a patente de uma rota de identificação e/ou do próprio gene implica publicar a sua localização e pode não garantir o acesso exclusivo ao gene. Além disso, o fato de esse gene ser encontrado em animais de concorrentes não significa que houve seleção deliberada dele e a prova em disputas pode ficar frágil. Embora tenha ocorrido uma ampliação do regime de propriedade, nos EUA e na Organização Mundial do Comércio (OMC), para contemplar a propriedade intelectual de produtos e processos da biotecnologia, há flancos abertos para discussões.

Nesse contexto, o segredo (conhecimento codificável e não publicado), o conhecimento tácito (conhecimento difícil de transmitir), a velocidade de inovação principalmente em produto - e a diversidade de produtos são fatores importantes de competitividade, já que o direito de propriedade intelectual para os métodos e as substâncias ligados ao conhecimento biotecnológico por vezes é controverso.

No Brasil, como a Lei de Patentes não prevê o patenteamento de genes de animais e de métodos de diagnóstico, mas protege os kits de identificação de genes, a incerteza é maior. No entanto, até o presente essa imprecisão jurídica não estrangula o grupo de genética suína, porque há uma complexidade técnica que se impõe e desafia até mesmo o regime internacional de propriedade já ampliado a genes de animais.

5 A Lei de Patentes Brasileira (de 1996) ampliou o raio de ação da propriedade intelectual após a Rodada Uruguai. Em relação aos seres vivos, apenas micro-organismos geneticamente modificados podem ser patenteados no Brasil. Os genes de plantas e de animais, os métodos terapêuticos e de diagnóstico para aplicação no corpo humano ou animal (Brasil, lei n.9.279, 1996, art. 10, incisos VIII e XIX, art. 18, inciso III) e os procedimentos biológicos (Dal Poz, Silveira \& Fonseca, 2004:381) não podem ser patenteados. 
No caso da regulamentação sanitária, as instituições que abrangem a sanidade dos rebanhos também são importantes para o SM de carne suína e para o desenvolvimento genético. Isso está associado ao maior interesse da população sobre a qualidade dos alimentos e a sua contaminação por medicamentos, além da possibilidade de resistência cruzada aos antibióticos. ${ }^{6}$

Em relação às doenças dos animais, os referenciais internacionais para controle e tratamento são determinados pela Organização Internacional de Epizootias (OIE). Os padrões e as normas sanitárias preconizadas pela instituição são reconhecidos pela OMC como de referência internacional.

Quanto aos resíduos e às contaminações dos alimentos de origem animal, o Acordo sobre a Aplicação de Medidas Sanitárias e Fitossanitárias, em vigor juntamente com a OMC em 1ํ de janeiro de 1995, refere-se à aplicação de regulamentações em matéria de inocuidade dos alimentos e controle sanitário dos animais e vegetais, incluindo o monitoramento de resíduos (Severo, 1999).

Os países participantes acordaram utilizar as normas de inocuidade dos alimentos elaboradas pela comissão mista Food and Agricultural Organization (FAO) e World Health Organization (WHO) do Codex Alimentarius. O Brasil adota as recomendações do Codex Alimentarius, do FSIS-USDA (Food Safety and Inspection Service - United States Departament of Agriculture), da União Europeia. Quando não há LMR desses órgãos, utiliza o padrão do sistema de mercado importador como referência no Plano Nacional de Controle de Resíduos Biológicos (PNCRB) em Produtos de Origem Animal (Severo, 1999).

A maior preocupação dos consumidores e a maior regulação possibilitam o surgimento de novos atores e alteraçôes nos contornos do ambiente seletivo, uma vez que as exigências sanitárias para a prevenção de doenças nos rebanhos impostas ao comércio de carne suína afetam o comércio de reprodutores vivos ${ }^{7}$ e o desenvolvimento genético. Por exemplo, o impedimento do comércio internacional de carne suína, devido aos fatores sanitários, para um destino com determinado padrão de

6 O resíduo de uma droga veterinária é a fração da droga, os produtos de conversão de reação e impurezas que permanecem no alimento originado de animais tratados com a droga. Nem todas as drogas e compostos químicos aos quais os animais ficam expostos deixam resíduos nocivos à saúde e, mesmo aqueles reconhecidos como potencialmente nocivos, somente permitem tal condição quando ultrapassam o valor de concentração conhecido como Limite Máximo de Resíduo (LMR). Esses limites são estabelecidos por especialistas que compõe o JECFA (Joint Expert Comitee on Food Addictives) do Codex Alimentarius, Programa das Nações Unidas sobre Harmonização das Normas Alimentares (Severo, 1999; Palermo-Neto, 1999).

7 Especificamente para a produção de suínos no Brasil, a certificação de sanidade GRSC (Granjas de Reprodutores Suídeos Certificadas) é feita pela Secretaria de Desenvolvimento Agropecuário (SDA) do Ministério da Agricultura, Pecuária e Abastecimento (MAPA), de acordo com as diretrizes do Plano Nacional de Sanidade Suídea (PNSS). Ela é necessária para a comercialização e distribuição, no Brasil, de suínos destinados à reprodução. 
demanda, implica que haverá menor desenvolvimento de produto para aquele padrão. Especificamente, o impedimento das exportações de carne suína para o Japão, devido à vulnerabilidade de um produtor à febre aftosa (por exemplo, o Brasil), implica um menor desenvolvimento de produtos com características genéticas de cor de carne e de gordura intramuscular que correspondam ao padrão japonês, e perda de competitividade em relação aos principais concorrentes internacionais, o Canadá, os Estados Unidos da América e a Dinamarca.

A genética animal pode constituir-se em um vetor auxiliar para a solução de problemas sanitários porque linhagens resistentes a doenças podem vir a ser desenvolvidas. Este é um veio tecnológico ainda incipiente e incerto, porém relevante. Nesse sentido, pode-se argumentar que a legislação sanitária de resíduos nos animais também importa ao segmento de genética suína, porque a necessidade de redução do uso de algumas drogas pode impulsionar o curso mencionado.

Sendo assim, é possível confrontar as duas trajetórias tecnológicas do segmento de genética suína com as características do ambiente de seleção (Rohenkohl, 2006). Uma ligada ao uso de genética quantitativa e melhoria dos aspectos de conversão alimentar e quantidade de carne na carcaça, existente já na década de 1980, e outra surgida nos anos 1990, que combina a genética quantitativa com a molecular e trabalha trade-off entre, de um lado, conversão alimentar/quantidade de carne na carcaça e, de outro, algum(ns) dos seguintes aspectos: prolificidade, teor de gordura intramuscular, cor e retenção de água da carne, resistência às doenças e redução do impacto ambiental.

As tecnologias de processo (genética quantitativa, genômica, reprodução artificial, manejo sanitário) envolvidas no trabalho de desenvolvimento genético estão em constante mudança, mas são, em suas linhas gerais, difundidas. A pesquisa em genética aplicada a suínos e de novas técnicas de reprodução é restrita a poucos países. A vantagem, em termos de cumulatividade de conhecimento, é das matrizes das firmas multinacionais que pesquisam em parceira com as universidades estrangeiras. Os elementos de competitividade no segmento são a capacidade de perceber as tendências e oportunidades do sistema de mercado da carne suína e seus reflexos no segmento de genética, a velocidade de inovar em produto, a manutenção de alto padrão sanitário dos rebanhos, o acesso e/ou a capacidade de criação de novas técnicas de reprodução e de melhoria nos processos de seleção de animais (Quadro 1). 
QUADRO 1

Planos das possibilidades inovativas em genética suína

\section{Trajetórias tecnológicas}

Trajetória 1 - sem trade-off entre maior quantidade de carne na carcaça, maior CA e redução de ET. Resultados são buscados com manipulações aditivas e complementares. Utiliza o paradigma da TI e biotecnologia tradicional (IA).

Apropriação - usa direito autoral e marcas.

\section{Possibilidade de aplicações}

Inovação em produto produtos com elevada CA e quantidade de carne na carcaça, boa prolificidade e sanidade, qualidade de carne, resistência a doenças; variabilidade genética nos rebanhos: volume de produção; assistência técnica.

Trajetória 2 - trade-off entre quantidade de carne na carcaça, maior CA e Inovação em processo genética quantitativa combinação de genética redução de ET, de um lado, quantitativa com genética e prolificidade ou qualidade molecular, parcerias de de carne ou resistência a doenças, de outro.

P\&D com universidades e organizações de pesquisa.

Combina $\mathrm{Tl}$, biotecnologia tradicional e genômica.

Apropriação - usa direito autoral, marcas e patentes de genes.

\section{Moldura do ambiente Resultados de seleção}

Paradigma tecnológico - Pouca eficácia das uso da TI para softwares patentes e ênfase nas estatísticos com controle marcas de produto e de e armazenamento de firmas contribuem para a dados de desempenho dos competitividade através da animais, gerenciamento de velocidade do incremento e granjas, análise qualitativa da inovação em produto. da carcaça e da carne, transmissão on-line de A preocupação com a dados de desempenho dos sanidade e seus reflexos animais e de qualidade da na legislação abrem carne e da carcaça. Uso da biotecnologia na IA, sexagem de sêmen, congelamento de sêmen e de embriões nos marcadores moleculares. perspectivas para a pesquisa de resistência genética a doenças, podendo vir a permitir a redução do uso de drogas.

Legislação sanitária - Ampliação da base LMRs nos animais. de conhecimento, principalmente com a Propriedade intelectual - evolução da biotecnologia patentes de genes ou segmentos genéticos, (desenvolvimento da biologia molecular) registro de marcas, direito implica maior necessidade autoral. de parcerias de $P \& D$.

Padrão de consumo A legislação sanitária mais segmentado e exigente quanto à incentiva o uso da genética molecular. dos produtos.

CA - conversão alimentar; ET - espessura de toucinho; LMR - limite máximo de resíduos; IA - inseminação artificial; TI - tecnologia da informação.

Fonte: elaborado pelos autores. 


\section{Configurações inovativas em desenvolvimento genético}

A configuração inovativa pode ser entendida como uma imagem mais detalhada da área de sobreposição entre o sistema tecnológico e o sistema de mercado. Nela visualizam-se tanto os fluxos de informação e compartilhamento de conhecimento - uma vez que as organizações envolvidas chegaram a um acordo quanto à distribuição do retorno proveniente da aplicação do conhecimento produzido (coordenação estratégica) -, como o fluxo de mercadorias e divisão de tarefas (coordenação operacional) entre firmas e organizaçōes de pesquisa. O surgimento de configurações inovativas está ligado às possibilidades de inovação decorrente desse íntimo relacionamento entre pesquisa e desenvolvimento tecnológico.

Teece (1998) define as alianças estratégicas como constelaçôes de acordos bilaterais ou multilaterais efetuados entre firmas, para desenvolver e comercializar nova tecnologia. Elas envolvem a coordenação estratégica, a qual aborda a distribuição do retorno da inovação e é especialmente importante em situaçōes que apresentam fraquezas na garantia da propriedade intelectual, e a coordenação operacional, que, por sua vez, abarca o aproveitamento de ativos complementares, a relação fornecedor e usuário e a conexão entre tecnologias complementares.

As alianças estratégicas são um formato organizacional adaptado a ambientes caracterizados pela rapidez da inovação e pela dispersão geográfica e organizacional do conhecimento (Teece, 1998:610).

Nesta seção são apresentadas duas configuraçōes internacionais resultantes da evolução de esforços inovativos e organizacionais no segmento de genética suína. Entendê-las é relevante, uma vez que o grupo de genética atua como um estimulador de inovações em nutrição e medicamentos veterinários, ${ }^{8}$ ou seja, esforços de melhoria nas raçōes e no manejo sanitário só se justificam quando aplicados a animais com potencial genético para alcançar um desempenho superior. Assim, a configuração inovativa é uma representação das relações em rede para a troca de informação e o compartilhamento de conhecimento entre agentes que caracterizam a pesquisa, o desenvolvimento de produto e de processo e a adaptação de produto que ocorre nos insumos para suínos, transcendendo fronteiras nacionais, em função da presença de importantes empresas multinacionais no segmento.

As mudanças das configurações inovativas e as mudanças organizacionais dentro de uma configuração desenrolam-se concomitantemente com a ampliação

8 Em geral, o polo dinâmico é a inovação e o desenvolvimento genético. Os segmentos de ração e de medicamentos figuram como ativos complementares no processo. 
do conhecimento e com as alterações nas perspectivas tecnológicas na pesquisa e no desenvolvimento genético em suínos. A extensão do direito de propriedade aos novos produtos e processos decorrentes do conhecimento biológico também contribui para a alteração das configuraçôes, na medida em que abre a perspectiva, ainda um tanto incerta, de remunerar patentes de organizações voltadas exclusivamente à $\mathrm{P} \& \mathrm{D}$ em biotecnologia aplicada à genética animal.

\subsection{Configuração com firma-chave}

A configuração com firma-chave está estabelecida desde a década de 1970. No centro do processo inovativo em questão, encontra-se uma firma-chave, de atuação internacional, dirigida ao desenvolvimento de genética e comercialização de reprodutores, matrizes, sêmen e de serviços ligados à genética suína. Essa firma participa ativamente da pesquisa e do processo de seleção de animais através de parcerias com universidades, em sua maioria norte-americanas e europeias (Figura 4). Desses esforços têm resultado, recentemente, patentes de métodos (processos) chamados marcadores genéticos ou moleculares, os quais propiciam a identificação de genes e de sua relação com alguma característica de valor econômico e social nos animais. Outros resultados desse esforço de pesquisa são os softwares de avaliação e armazenagem de desempenho dos animais de diversas geraçôes, bem como o desenvolvimento e a melhoria nas técnicas de reprodução (transferência de embrião, inseminação artificial, sexagem de sêmen).

A pesquisa genômica ainda é incerta. Há milhares de genes a serem pesquisados em busca de relações com diversas características produtivas e qualitativas. Além disso, as leituras de DNA ainda são caras ${ }^{9}$ (Bergmann, 2005).

O desenvolvimento de novas linhas tanto pode ser feito pela firma-chave como por uma organização associada a ela, à qual é repassada a tecnologia de marcadores genéticos para o desenvolvimento de novas linhas. Representantes comerciais, filiais, joint ventures e universidades de diferentes países, inclusive do Brasil, estão envolvidas nessa etapa. Nesse caso, o esforço de desenvolvimento de produto não requer uma pesquisa sofisticada, pois decorre muito mais da aplicação de métodos já consolidados. É importante dispor de uma grande variabilidade genética nos rebanhos da firma-chave, de forma que inúmeras combinaçôes possam ser averiguadas. Laboratórios de universidades e centros de pesquisa, como o Instituto de Tecnologia de Alimentos do Estado de São Paulo (ITAL-SP), participam da análise

9 O teste de um gene por animal custa no mínimo US\$1,00. 
de carcaças e da carne, auxiliando na avaliação dos resultados através de rotinas que realimentam o desenvolvimento.

A configuração da firma-chave é completada pelo esforço de adaptação e multiplicação da genética desenvolvida. Os animais bisavós, de alto potencial genético, são multiplicados em avós ou em matrizes e reprodutores que se destinam à venda para plantéis de criadores de suínos. O trabalho de multiplicação a partir de um rebanho-núcleo da firma-chave pode ser conduzido por esta ou por um terceiro especialmente contratado para tanto, que deverá apresentar condiçóes de elevado padrão sanitário e de manejo para atender aos requisitos de qualidade da firma-chave. As granjas de multiplicação também monitoram o desempenho dos animais criados em suas instalações e abastecem a firma-chave com informações através dos programas informatizados de transmissão de dados. Aqui há outro ciclo de realimentação para orientar a inovação futura. Essas informações constituem um enorme banco de dados de animais oriundos da genética desenvolvida pela firma-chave e ajudam a direcionar o desenvolvimento de novas linhas genéticas.

$\mathrm{Na}$ configuração da firma-chave, a cooperação/coordenação em torno da inovação - tanto em pesquisa, como no desenvolvimento de novas linhas ou em pequenos incrementos de produtividade e de qualidade de uma geração de animais para a outra dentro da mesma linha genética - ocorre sob coordenação da firmachave. A capacidade de P\&D interno da firma-chave é bastante desenvolvida, mas não chega a ocorrer uma integração vertical da $\mathrm{P} \& \mathrm{D}$ à comercialização. Há uma combinação de coordenação interna e externa à firma, com as parcerias com universidades e centros de pesquisa funcionando como membros auxiliares importantes, ligados ao corpo coordenado pela firma-chave.

A Pig Improvement Company (PIC) é uma firma-chave, líder mundial em genética suína, atua em mais de 30 países. De origem inglesa, possui dois centros de pesquisa próprios, um na Inglaterra e outro nos Estados Unidos da América. Estabelece parcerias de pesquisas na Europa, nos Estados Unidos da América e na China. No Brasil, é acionista de uma join venture com um grupo local, a Agroceres-PIC. A join venture brasileira possui autonomia para desenvolver algumas linhas genéticas a partir do núcleo genético da multinacional. Para tanto, repassa a tecnologia de marcadores genéticos da firma-chave para uma universidade brasileira, que os utiliza para testar se os animais da nova linha possuem o fragmento genético desejado. A condução da seleção é complementada pelo acúmulo de dados de desempenho desses animais e de seus parentes. Tais informaçōes acabam abastecendo o banco de dados mundial da firma-chave. 


\section{FIGURA 4}

Configuração inovativa da firma-chave

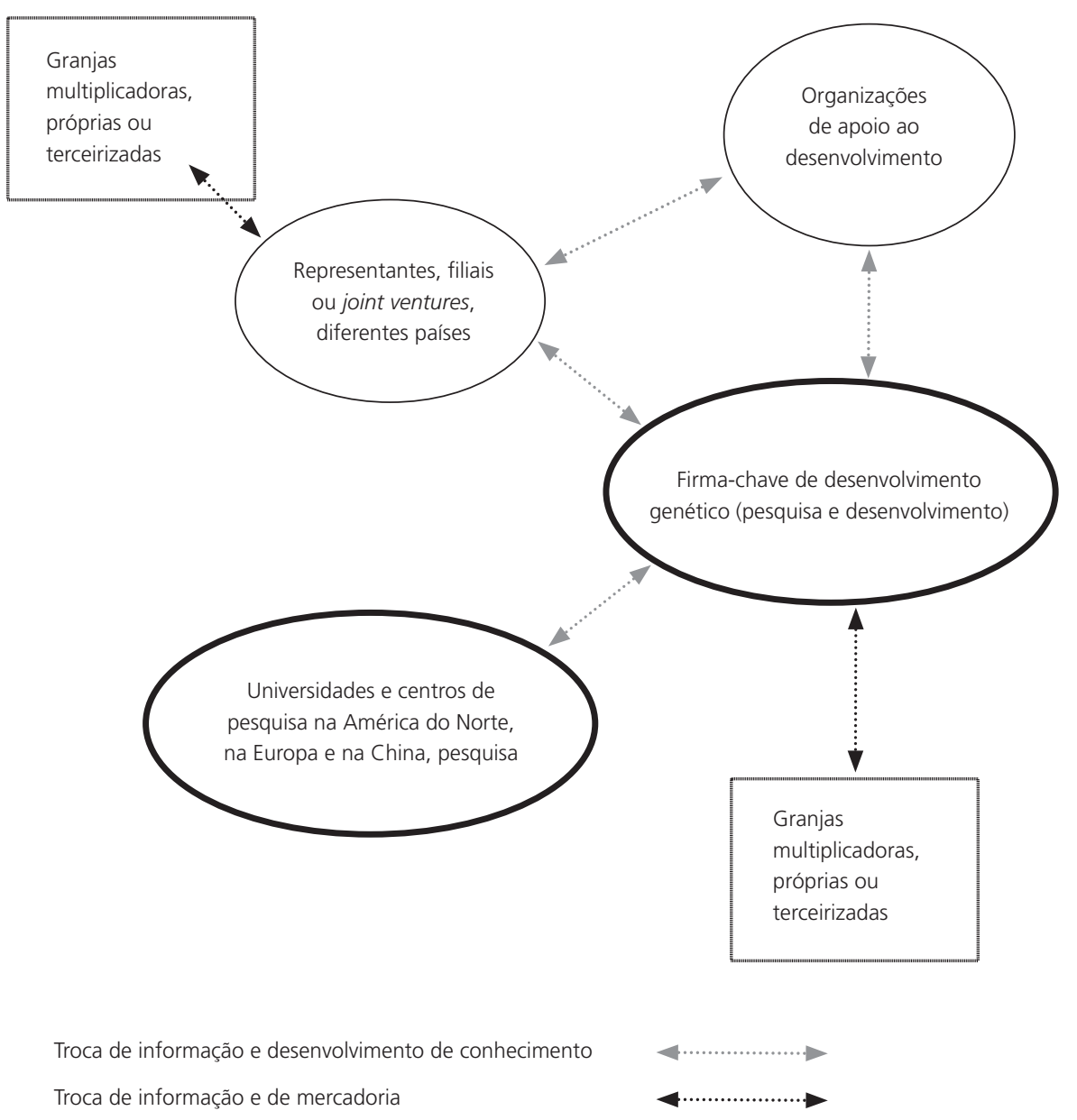

Fonte: elaborado pelos autores.

A PIC extrapolou a atuação em genética suína e foi incorporada a um conglomerado empresarial de pesquisa e comercialização de genética animal, a Sygen. Além da PIC, a Sygen controla a SyAqua, que desenvolve genética de camarôes. $\mathrm{O}$ conhecimento e a infraestrutura de inovação acumulados em genética de suínos possibilitaram economia de escopo. A combinação de genética quantitativa e de genética molecular está sendo estendida para o desenvolvimento tecnológico de 
outras espécies. A Sygen identificou 44 marcadores genéticos em suas pesquisas, contemplando porcos, frangos, bovinos e camarôes. Segundo o relatório anual da Sygen, para o ano fiscal encerrado em 30 de junho de 2004 o faturamento anual alcançou US\$ 235 milhôes, com dispêndio de US\$ 13 milhôes (ou cerca de 5,5\% do faturamento) em atividades de $\mathrm{P} \& \mathrm{D} .{ }^{10} \mathrm{O}$ lucro operacional da firma subsidiária PIC alcançou US\$26,72 milhôes. No final de 2005, a Sygen foi adquirida pela firma de genética bovina Genuc plc, reforçando a possibilidade de explorar a economia de escopo interespécies decorrente da P\&D em genética.

Outra firma-chave, a Génétiporc, de expansão mais recente, tem origem no Canadá. Faz parte do grupo industrial de alimentos Breton, que atua no abate e processamento de carne suína, na produção de ovos, em rações animais e na produção de alimentos pré-embalados. Além do Canadá, o grupo tem ação nos EUA, no México e no Brasil. No Brasil atua através de uma join venture com a Vitagri, firma do grupo Nutrimental, especializada em soluções para a nutrição animal. A Génétiporc possui parcerias com centros de pesquisa na Europa, nos EUA e no Canadá, tendo desenvolvido o seu software de seleção genética.

\subsection{Configuração modular}

A multiplicação de possibilidades de inovação - avanços na biologia molecular nos anos de 1970-1990 e no direito de propriedade intelectual, alterando as perspectivas tecnológicas na $P \& D$ de genética suína - proporciona condições para a eclosão de nova configuração, denominada aqui de configuração modular (Figura 5).

Essa configuração difere da primeira pela formalização da separação, em firmas diferentes, da etapa de pesquisa e da fase de desenvolvimento de linhas genéticas. Há uma maior coordenação da inovação externa à firma de desenvolvimento, que agora compartilha o eixo do processo inovativo com a firma especializada em pesquisa. Isso não implica uma coordenação de mercado, entendido em sua idealização mais radical de mercado de competição perfeita, com livre circulação de informação e de conhecimento. Por outro lado, os parceiros de pesquisa não são mais apenas organizaçôes extramercado (universidades e centros de pesquisa públicos) análogas a membros auxiliares, alguns são firmas de pesquisa e adquirem funções vitais no corpo inovativo e comercial da nova configuração.

10 A PIC desenvolve atualmente 17 linhas genéticas. O desenvolvimento de uma linha macho terminador leva de 3 a 4 anos. O custo de desenvolvimento do macho MS 60 da Embrapa foi de aproximadamente US\$620 mil. Uma linha fêmea pode demorar até 8 anos para ser desenvolvida. 


\section{FIGURA 5}

Configuração inovativa modular

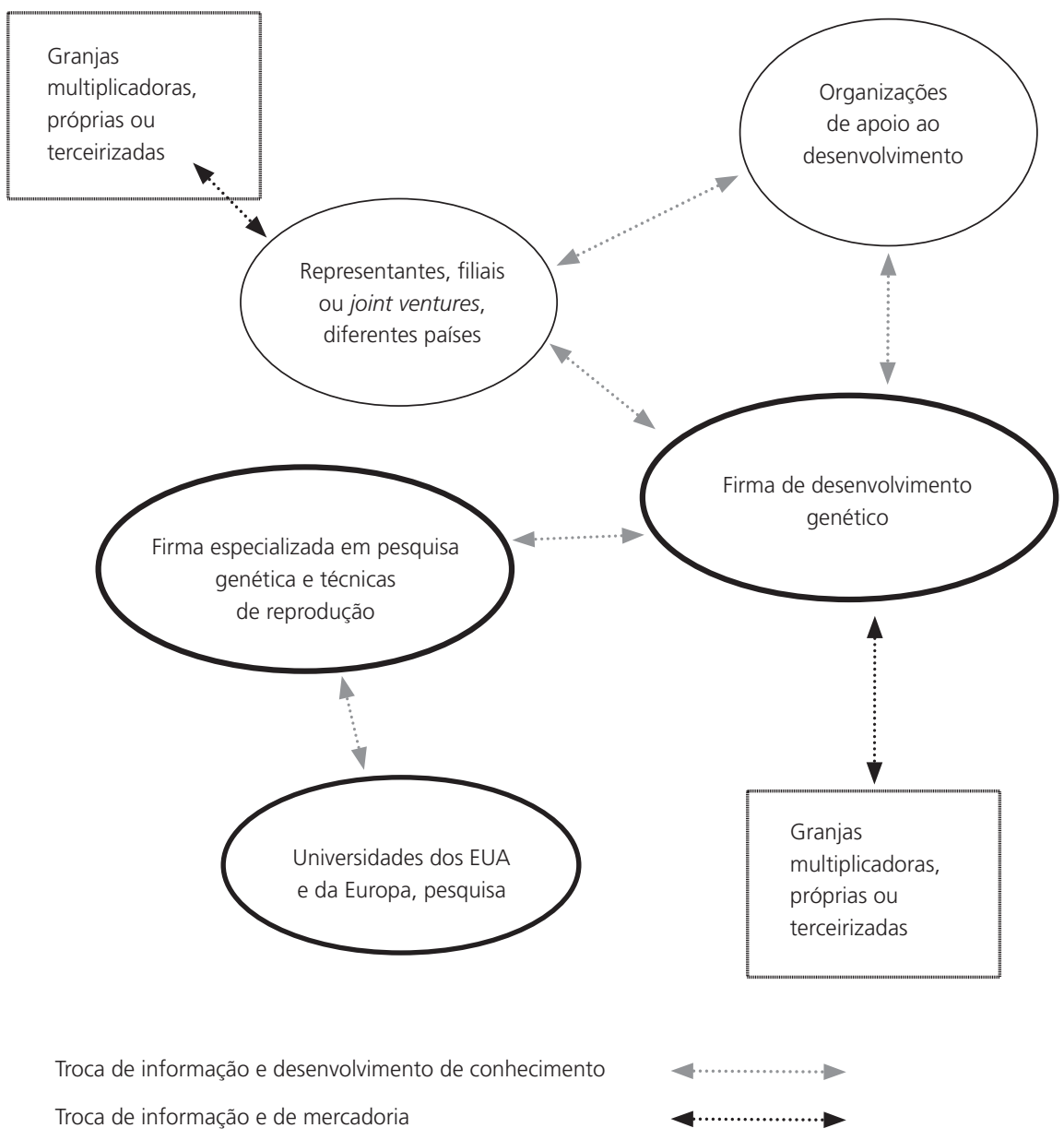

Fonte: elaborado pelos autores.

A firma de pesquisa é especializada em genética e em técnicas de reprodução. Nessa configuração é ela quem estabelece parcerias com universidades. Algumas dessas firmas desenvolvem pesquisas para diferentes espécies animais, bem como técnicas que podem resultar em inovações aplicadas à indústria farmacêuticas. A ação de algumas delas, como a Metamorphix INC e a Gentec, ocorre nos moldes das New Biotech Firms (NBF) descritas por Pisano et al. (1998) e Mckelvey e 
Orsenigo (2001). Elas mobilizam conhecimento relevante criado em universidades e o transformam em processos aplicados e em produtos comercializáveis.

Já a firma de desenvolvimento genético trabalha voltada mais ao desenvolvimento de produto e para o estabelecimento de uma ampla rede de reprodução e de comercialização de animais. Possui menor capacidade de pesquisa comparativamente à sua parceira. Suas ligaçôes com filiais, com organizaçôes parceiras no desenvolvimento de linhas genéticas e com multiplicadores seguem o mesmo padrão da firma-chave.

A firma de pesquisa e a firma de desenvolvimento genético desenvolvem relaçôes de longo prazo, o que incluem participaçóes de capital dos mesmos agentes em ambas, com percentuais distintos, ou contratos de desenvolvimento de esforços inovativos.

O primeiro exemplo da configuração modular (Figura 5) refere-se à Topigs, uma firma de desenvolvimento genético sediada na Holanda, com operações em 30 países. $\mathrm{O}$ investimento anual nas áreas de genética (quantitativa e molecular), inseminação artificial e transferências de embriôes atualmente está em torno de US\$ 5 milhōes, e é conduzido por uma firma do grupo, o Institute for Pigs Genetics (IPG), criada em 1997 e especializada em pesquisa. O IPG conta com 11 geneticistas e 35 funcionários de apoio. Ele também desenvolve softwares e armazena dados da criação. Semanalmente, as granjas-núcleo, as multiplicadoras e as granjas comerciais ligadas à Topigs em diferentes partes do mundo enviam eletronicamente back-ups, contendo informações sobre seus plantéis para o IPG. O banco de dados reúne informações de mais de 10 milhôes de animais. A coleta de dados envolve os animais puros que estão nas granjas-núcleos e também os animais das camadas mais inferiores na pirâmide de produção, ou seja, avós, matrizes e cevados, a fim de orientar as combinaçôes entre raças e linhas. O IPG frisa que não desenvolve animais geneticamente modificados (OGM). Isso denota uma preocupação com uma possível reação de consumidores temerosos quanto aos efeitos de OGM e representa um aspecto sutil e informal de valores e crenças que moldam comportamento de consumo e que fazem parte de uma dimensão socioeconômica do ambiente seletivo.

O IPG mantém contatos de pesquisa com universidades holandesas (Wageningen e Utrecht), com o Institut National de Recherche Agronomique INRA da França e com a Universidade de Bonn, na Alemanha. Ele também presta serviços de desenvolvimento de software e gerenciamento de dados para a Aliança de Inseminação Artificial das Cooperativas de Porcos da Dinamarca.

Outro caso da configuração modular é oriundo da reestruturação da Seghers, ocorrida em 2002. Ela envolve duas firmas de desenvolvimento em genética suína - 
a Rattlerow Seghers, sediada na Bélgica, e a Newsham, dos Estados Unidos ${ }^{11}$-, coproprietárias de uma terceira, a Gentec, especializada em pesquisa em genética animal. O principal objetivo da Gentec é identificar marcadores genéticos que contribuam para a qualidade da carcaça e da carne, o crescimento, a prolificidade e a identificação de hereditariedade de defeitos congênitos nos animais. Ela também dedica esforços ao desenvolvimento de técnicas de transferência de embrióes.

Mais um exemplo da configuração modular é encontrado nos EUA, na parceria de P\&D estabelecida em 2004 entre a Metamorphix Inc. e a Monsanto Choice Genetics. A Metamorphix possui a capacitação em análises de DNA, em genética animal e humana, e em desenvolvimento de drogas chamadas "imunofarmacêuticas". A parceria visa ao mapeamento do genoma dos suínos para a Monsanto, que, embora possua capacidade em pesquisa genética, necessita da especialidade de a Metamorphix acelerar a identificação de "locais genéticos" responsáveis pela transmissão de características de valor econômico nos animais. No plano comercial, a Monsanto adquiriu uma firma tradicional de genética do Canadá (Unipork), que é uma rede comercial e de multiplicação de matrizes espalhadas pelos EUA e pelo Canadá. ${ }^{12}$

Grosso modo, as duas configuraçōes inovativas descritas apresentam mudanças organizacionais que acompanham alteraçôes da base de conhecimento usada em desenvolvimento genético. A própria firma-chave surgiu com a PIC em um momento de mudança, da seleção artesanal para a dirigida pela quantificação sistemática da capacidade produtiva dos animais. Ela mantém-se na configuração de firma-chave, incrementando a sua ação com a busca de economia de escopo (camarões, bovinos). Ao longo do movimento internacional de transformação da inovação, algumas firmas reorganizam sua oferta inovativa (Topigs, Seghers/Gentec) e passam a utilizar a configuração modular. Outras firmas adentraram o SM tentando também distintas configurações (Monsanto na configuração modular e Génétiporc na firma-chave). Isso pode ser explicado pelas particularidades de competências internas acumuladas e pelas visões de negócios que interferem nas decisões estratégicas e que possibilitam a convivêncvia de configurações no mesmo contexto de inovação.

Em um contexto de rápida mudança tecnológica, os acordos de cooperação possibilitam às firmas obter recursos complementares e insumos tecnológicos essenciais, minimizando riscos e mantendo a possibilidade de se descomprometerem (Chesnais, 1996:143-44). A perspectiva de ampliar o conhecimento e acelerar

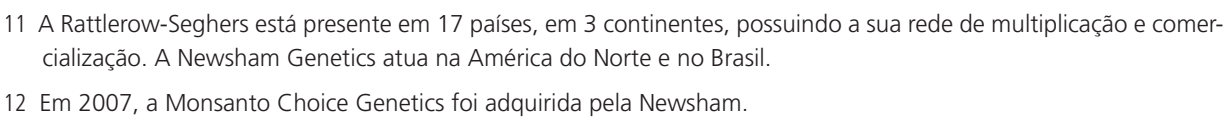


o desenvolvimento através do compartilhamento de pesquisa com organizaçōes parceiras é uma estratégia competitiva. Nessa perspectiva, a configuração modular é interessante diante das maiores possibilidades técnicas presentes na inovação, tentando contornar o excesso de burocratização que a integração vertical implica e que pode oprimir a criação de soluçóes, bem como permitindo o acesso rápido e simultâneo a um amplo leque de frentes de pesquisa.

Concomitantemente, o direito de propriedade estendido à genômica aplicada na seleção genética de animais não proporciona ainda garantia de sustentação lucrativa com os direitos de propriedade sobre genes e processos de associação entre genes e característica, a principal trajetória atual. Logo, as firmas especializadas em pesquisa não são completamente independentes, são braços de pesquisa especializados, com liberdade de criar soluçóes, mas coordenados pelas firmas de desenvolvimento genético. Caso uma trajetória que envolva, por exemplo, engenharia genética, ou outra técnica mais afeita à remuneração através de direitos de propriedade intelectual, sobressaia no grupo, firmas de pesquisa especializada realmente independentes devem surgir nos moldes da Metamorphix INC.

As duas configurações ajustam-se a uma representação de inovação setorial em modelo interativo e sistêmico (Figura 6). Em ambas há pontos de realimentação vitais para a direção da inovação. As informações dos testes de qualidade de carcaça e de carne, e de desempenho dos animais, realizadas por instituiçôes de apoio ao desenvolvimento de linhas orientam novas rotas (e/ou aprimoramento de velhas) de pesquisa. Por exemplo, os problemas de resistência de bactérias aos antibióticos são desafios ao desenvolvimento genético. As soluções são pesquisadas pelo grupo de medicamentos, mas a procura de genes relacionados com a resistência dos animais às doenças pelo desenvolvimento genético é um caminho alternativo. Isso revela uma demanda da criação animal e da produção de carne em contato com o SM consumidor e com as instituições de regulação sanitária, que colocam um desafio à pesquisa. Os testes dos animais balizarão correçôes de rumo. Há, claramente, uma interação entre as oportunidades/os estrangulamentos de SM, a base de conhecimento e a capacitação das firmas.

Quando há a separação entre pesquisa e desenvolvimento em firmas diferentes, ou seja, a configuração de inovação modular, o financiamento costuma fluir da firma de desenvolvimento para a de pesquisa.

O modelo interativo de organização da inovação requer um grau de descentralização da P\&D para a aproximação dos clientes. Uma evolução nesse sentido é facilitada pelas novas possibilidades de coordenação e controle proporcionadas pela 
FIGURA 6

Interação na inovação em desenvolvimento genético

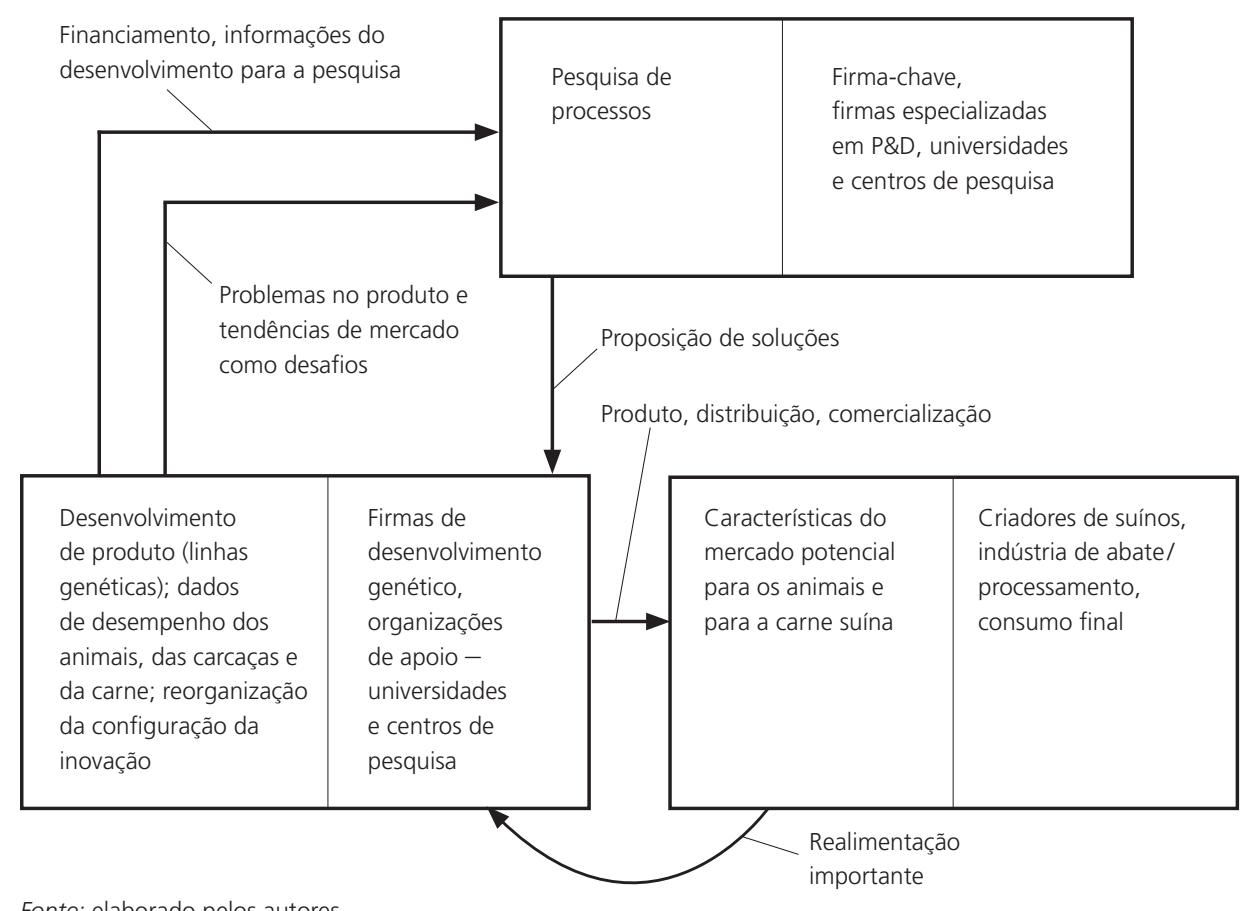

Fonte: elaborado pelos autores.

telemática [ou Tecnologia da Informação] da P\&D internacionalizada (Chesnais, 1996:151-152). Na genética suína, a aproximação do cliente para o aprendizado parece estar impulsionando uma descentralização do desenvolvimento de produto para captar as peculiaridades de sistemas de mercado regionais.

\section{Considerações finais}

Este trabalho procurou reunir elementos teóricos e analíticos para discutir - numa perspectiva sistêmica - as principais características e mudanças recentes nas configurações tecnológicas e organizacionais no segmento de genética suína. Pode-se verificar a riqueza e a complexidade dos elementos tecnológicos e socioinstitucionais nos diversos planos analíticos, mesmo que restrito a um segmento delimitado e exíguo - o desenvolvimento genético. 
O desenvolvimento genético amplia o processo de "descommoditização" do animal e da sua carne, permitindo que o espaço para a agregação de valor ocorra também, de modo mais explícito, antes do beneficiamento industrial da carne suína em produtos derivados. Vale dizer, o próprio produto primário é objeto de diferenciação com a utilização de tecnologias genéricas como a biotecnologia e a TI, seja para explorar segmentaçôes de mercado do produto in natura, seja para adequar o produto primário e potencializar as modificaçōes posteriores de processamento da carne. A lógica do desenvolvimento de um novo produto derivado de carne suína pode iniciar nos insumidores e estar coordenado com o abate e o processamento de carne. Isso dá uma nova dimensão à inovação, em que a coordenação vai além da "cadeia produtiva" de carne e abarca um sistema tecnológico e um sistema de mercado.

Nesse sentido, o termo pseudocommodities é cada vez mais adequado para retratar os animais e a sua carne em função das modificações que os insumos da criação animal proporcionam a esses artefatos. Rebanhos de animais têm características de genética, de nutrição e de manejo sanitário específicas para as linhas de produto final - produtos de animais sem traços de antibióticos, linha genética de suíno específica para embutido específico, carne no padrão de cor apreciado pela cultura de determinado país, e assim por diante. As possibilidades de diferenciaçôes nos animais e na carne multiplicam-se, e capacitar-se e coordenar a utilização da tecnologia capaz de tal diferenciação qualitativa é um trunfo competitivo.

Numa perspectiva sistêmica, pode-se afirmar que se delineia no segmento de desenvolvimento genético um padrão de concorrência calcado na capacidade de perceber rapidamente as mudanças do sistema de mercado de carne suína e responder a elas com o lançamento de novas linhas genéticas ou o incremento das antigas (Rohenkohl, 2006). As oportunidades são elevadas, dado que a combinação de softwares com a biotecnologia moderna pode levar a uma ampliação do espaço de desenho para além da genética quantitativa e da genômica aplicada a suínos, com a utilização de porcos geneticamente modificados - transgênicos ou não -, e da cooperação com pesquisas em saúde humana. Também surgem oportunidades pelo alargamento da aplicação do espaço de desenho ora explorado através do ganho de escopo - com a extensão das práticas correntes de busca genômica a outras espécies. Percebe-se a permeabilidade de outros campos que podem propiciar retorno aos investimentos em P\&D das organizações de pesquisa e das firmas de desenvolvimento genético.

Para tanto, é fundamental ter acesso a um banco genético com grande variabilidade e capacidade de predição acurada quanto ao desempenho produtivo das novas linhas genéticas desenvolvidas. Também é importante pesquisar novos processos de 
seleção e novas técnicas de reprodução. Com esse objetivo, as firmas líderes cooperam com outras organizações, assim, a flexibilidade organizacional para acessar e compor rapidamente as diversas fontes de conhecimento relevantes para o desenvolvimento do produto/processo torna-se um fator de competitividade. Além disso, constituir uma ampla base de comercialização dos animais é requisito necessário para atender às diversas nuanças do sistema de mercado e sustentar os investimentos em $P \& D$.

A apropriação de conhecimentos e de inovações decorrentes da pesquisa e do desenvolvimento está mais relacionada ao segredo industrial, ao registro de marca das firmas e/ou produtos e ao direito autoral, com algumas firmas apostando nas patentes de genes. No entanto, o direito de propriedade para os genes de indivíduos não tornou as patentes uma forma eficaz de apropriação do conhecimento em genética suína.

Se a propriedade privada do conhecimento em alguns aspectos relativos à genética animal está pouco efetiva, por outro lado, o ímpeto concorrencial interno ao SM em torno de inovação e diferenciação de produto impulsiona a transformação da mercadoria e a variedade de comportamento das firmas. A velocidade da inovação e da diferenciação passa a ser fundamental para obter os lucros extraordinários. Atualmente, no centro das configurações inovativas do desenvolvimento genético estão postadas firmas multinacionais que coordenam o uso de boa parte do conhecimento aplicado e relevante decorrente de esforços cooperativos de P\&D. Isso lhes confere trunfos competitivos decorrentes do acesso em primeira mão ao conhecimento necessário para avançar em fatias maiores de mercado e agregar valor mais intensamente.

Porém a estratégia de firmas multinacionais de delegarem às filiais algumas atribuições relativas à $\mathrm{P} \& \mathrm{D}$ se verifica em alguma medida no desenvolvimento genético. Nesse aspecto, há oportunidades para capacitação tecnológica para as firmas brasileiras que estão participando no desenvolvimento de produto, em específico em linhas macho terminador. $\mathrm{O}$ fenômeno de ampliação da base de conhecimento utilizada - não dominada completamente por nenhum agente individualmente e a necessidade das firmas de desenvolvimento genético de conhecerem e desenvolverem produtos dirigidos às especificidades dos diversos segmentos do SM são elementos que propiciam uma porosidade do ambiente seletivo relativo à inovação em genética para a qualificação de organizações brasileiras e sua penetração em direção ao centro das configuraçôes inovativas. É preciso garantir que os esforços para desenvolver novas linhas localmente tenham continuidade e inspirem parcerias de organizações de pesquisa brasileiras com firmas de capital nacional ou estrangeiro, 
ou entre firmas nacionais e estrangeiras, adquirindo um caráter sistêmico no grupo de desenvolvimento genético e provocando, consequentemente, efeitos positivos em todo o segmento de insumos para suínos brasileiro. Obter-se-á, então, uma dinâmica inovativa consolidada. Nesse sentido, pode ser interessante o maior incentivo para parcerias de cooperação para o desenvolvimento tecnológico, bem como aproximações entre firmas de genética suína com outras de genética bovina, e entre ambas com firmas de pesquisa da indústria farmacêutica, combinações que podem alterar os limites do ambiente seletivo, inserindo novos agentes, novas relaçóes entre eles e novos produtos ou novos usos para o suíno.

A forte inserção no ST internacional através do grupo insumidor de desenvolvimento genético - mesmo que ocorra sem uma firma de capital brasileiro no papel de firma-chave, ou no de firma de pesquisa - pode proporcionar transbordamentos positivos pelo acúmulo de conhecimentos nas firmas, nas universidades e nos centros de pesquisas participantes. Isso aumentará a robustez competitiva da indústria nacional no longo prazo e, caso novos padrões internacionais sanitários e de qualidade de carne, mudanças de paradigma tecnológico, crises envolvendo doenças ou segurança alimentar, entre outras possibilidades surjam no horizonte da indústria de carne suína, os insumos da criação, em especial no desenvolvimento genético, serão um vetor de oferta de soluções. No entanto, a melhor definição da legislação brasileira acerca dos processos biológicos e dos métodos terapêuticos e de diagnóstico poderia encorajar o patenteamento por parte de organizaçóes nacionais e lhes propiciar maior potencial de barganha em parcerias de cooperação em $\mathrm{P} \& \mathrm{D}$. Isso poderia aumentar, aos centros de pesquisa e às firmas nacionais, a probabilidade de formação de conexões de pesquisas internacionais mais densas e profícuas, em termos financeiros e estratégicos. 


\section{Referências bibliográficas}

ABIPECS - Associação Brasileira das Indústrias Produtoras e Exportadoras de Carne Suína. Disponível em <http://www.abipecs.org.br/pt/estatisticas/mundial/producao-2.html>. Acesso em 10 de março de 2008.

ACSURS - Associação de Criadores de Suínos do Rio Grande do Sul. Disponível em <http:// www.acsurs.com.br/index_conteudo.asp?cod=1505>. Acesso em 6 de maio de 2008.

Andersen, H.J. "What is pork quality?", in Wenk, Caspar et al., Quality of meat and fat in pigs as affected by genetics and nutrition. Zurique: European Association for Animal Production - EAAP, 2000, Publication, n.100.

Bergmann, J.A.G. "A genética molecular no melhoramento suíno: vantagens e limitaçôes". Disponível em <http://www.dbdanbred.com.br>. Acesso em 10 de março de 2005.

Brasil. Ministério da Agricultura, Pecuária e Abastecimento. "Plano Nacional de Sanidade Suídea”. Disponível em <http:// www.agricultura.gov.br>. Acesso em 26 de maio de 2006.

Lei n.9.279, de 14 de maio de 1996. Ementa da lei. Disponível em <http//:www. planalto.gov.br/CCIVIL/Leis/L9279.htm>. Acesso em 14 de fevereiro de 2007.

Carlsson, B.; Stankiewicz, R. "On the nature, function and composition of technological systems", Journal of Evolutionary Economics, v.1, p.93-118, 1991.

Carlsson, B. et al. "Innovations systems: analytical and methodological issues", 1999. Disponível em <http://www.druid.dk/conf-papers-attach/carlsson.pdf>. Acesso em $25 \mathrm{de}$ maio de 2006.

Carlsson, B.; Eliasson, G. "Industrial dynamic and endogenous growth", Industry and Innovation, Londres, v.10, n.4, p.435-455, 2003.

Chamas, C.I.; Barata, M.; Azevedo, A. "Proteção intelectual de invenções biotecnológicas", Encontro da Associação Nacional de Pós-Graduação em Administração, 28. Curitiba, ANPAD, 2004, CD-ROM.

Chesnais, F. A mundialização do capital. São Paulo: Xamã, 1996.

Chevassus-Lozza, E.; Gallezot, J. "La différenciation des produits dans la compétitivité: le cas de l'agriculture et de l'agro-alimentaire français”, in Nicolas, François; Valcheschini, Egizio (ed.), Agro-alimentaire: une économie de la qualité. Paris: INRA Economica, 1995.

Cimoli, Mario; Dosi, Giovanni. "De los paradigmas tecnológicos a los sistemas nacionales de producción e innovación”, Comercio Exterior, México, v.44, n.8, p.669-682, ago., 1994. 
Dal Poz, M.E.; Silveira, J.M.F.J.; Fonseca; M.G.F. "Direitos de propriedade intelectual em biotecnologia: um processo em construção", in Silveira, José Maria F.J. da; Dal Poz, Maria Ester; Assad, Ana Lúcia D. (orgs.), Biotecnologia e recursos genéticos: desafios e oportunidades para o Brasil. Campinas: Instituto de Economia, UNICAMP, FINEP, 2004.

Dosi, Giovanni. “Technological paradigms and technological trajectories”, Research Policy, Elsevier, v.11, n.3, p.147-162, 1982.

Eymard-Duvernay, F. "Conventions de qualité et formes de coordination", Revue de Économique, n.2, p.329-359, mar., 1989.

"La négociation de la qualité", in Nicolas, François; Valcheschini, Egizio (ed.), Agro-alimentaire: une économie de la qualité. Paris: INRA Economica, 1995.

Furtado, J. "Padrões de inovação na indústria brasileira", 2004. Disponível em <http:// www.ifhc.org.br/HistEvento.aspx?mn=11\&id=11>. Acesso em 10 de março de 2008.

Gomes, M.F.M. et al. Análise prospectiva do complexo agroindustrial de suinos no Brasil. Concórdia: Embrapa, CNPSA, 1992.

Kupfer, David. "Padrōes de concorrência e competitividade". Disponível em <http://ww2. ie.ufrj.br/gic/pdfs/1992-2_Kupfer.pdf>. Acesso em 9 de janeiro de 2007.

Mckelvey, M.; Orsenigo, L. "Pharmaceuticals as a sectoral innovation system", paper prepared for the ESSY Project (European Sectoral System of Innovation), 2001.

Metcalfe, J.S. "Equilibrium and evolutionary foundations of competition and technology policy: new perpectives on the division of labour and the innovation process", Revista Brasileira de Inovação, Rio de Janeiro, v.2, n.1, p.111-146, jan.-jun., 2003.

Murakami, T. "Os impactos da mudança de paradigma tecnológico do setor de biotecnologia nos grupos 'insumidores' de nutrição e sanidade para a indústria de processamento de carne de aves e de suínos e seus desdobramentos na relação usuário-produtor”, Monografia de Graduação em Ciências Econômicas, Universidade Estadual Paulista. Araraquara, 2006.

Palermo-Neto, J. "Resíduos e aspectos toxicológicos: possíveis impactos na qualidade da proteína de origem animal", in Anais do Simpósio sobre as Implicaçôes Sócio-Econômicas do Uso de Aditivos na Produção Animal. Piracicaba: Colégio Brasileiro de Nutrição Animal, Embrapa, CNPSA, 1999.

Pessanha, L.D.R.; Wilkinson, J. "Transgênicos provocam novo quadro regulatório e novas formas de coordenação do sistema agroalimentar”, Cadernos de Ciência e Tecnologia, Brasília, v.20, n.2, p.263-303, maio-ago., 2003. 
Pisano, G.P.; Shan, W.; Teece, D. "Joint ventures and collaboration in the biotechnology industry", in Economic performance and the theory of the firm: the selected papers of David Teece. Cheltenham: Edward Elgar, 1998, v.1.

Possas, M.L. Estrutura de mercado em oligopólio. São Paulo: HUCITEC, 1985.

Rohenkohl, J.E. "Configurações institucionais e ambiente seletivo: um estudo econômico das trajetórias de inovação em genética suína no Brasil”, Tese de Doutorado, Programa de Desenvolvimento Rural, Faculdade de Ciências Econômicas, Universidade Federal do Rio Grande do Sul. Porto Alegre, 2006.

Rohenkohl, J.E.; Martinelli Júnior, O. Relatório setorial final: genética suína, parte do projeto de pesquisa Diretório da Pesquisa Privada no Brasil - DPP_FINEP_FUNDUNESP, 2007.

Santini, G. et al. Relatório setorial final: insumos suinos, parte do projeto de pesquisa Diretório da Pesquisa Privada no Brasil - DPP-FINEP_FUNDUNESP, 2004.

Severo, M.P.F. "Resíduos em produtos de origem animal no Brasil: o papel do Ministério da Agricultura e do Abastecimento", in Anais do Simpósio sobre as Implicaçôes SócioEconômicas do Uso de Aditivos na Produção Animal. Piracicaba: Colégio Brasileiro de Nutrição Animal, Embrapa, CNPSA, 1999.

Teece, D. "Competition, cooperation, and innovation: organizational arrangements for regimes of rapid technological progress", in Economic performance and the theory of the firm: the selected papers of David Teece. Cheltenham: Edward Elgar, 1998, v.1.

ENDERECOOS PARA CORRESPONDENCIA:

Julio Rohenkohl-julioroh@gmail.com

Orlando Martinelli-orlando.martinelli@gmail.com

Universidade Federal de Santa Maria

Rua Floriano Peixoto 1750 - 6o andar

Centro, Santa Maria - RS

CEP 97015-372 